\title{
A COMPARATIVE STUDY OF FORMATIVE ASSESSMENT TOOLS
}

\author{
Tasaratha Rajan Anamalai ${ }^{1}$ \\ Fakulti Seni, Komputeran dan Idustri Kreatif, \\ Universiti Pendidikan Sultan Idris (UPSI), Malaysia. \\ (Email: tasara83@gmail.com) \\ Maizatul Hayati bt Mohamad Yatim² \\ Fakulti Seni, Komputeran dan Idustri Kreatif, \\ Universiti Pendidikan Sultan Idris (UPSI), Malaysia. \\ (Email: maizatul@fskik.upsi.edu.my)
}

Received date: 18-07-2019

Revised date: 01-08-2019

Accepted date: 03-08-2019

Published date: 12-09-2019

To cite this document: Anamalai, T. R., \& Yatim, M. H. M. (2019). A Comparative Study of Formative Assessment Tools. Journal of Information System and Technology Management, 4(14), 61-71.

DOI: $10.35631 /$ jistm.414006

\begin{abstract}
The intention of formative assessment tools usage is mainly to assess learning outcomes easily and quickly in a classroom environment. However, the tools need to be accurate and informative for teachers and students. At the end of any learning process, students certainly need to know their level of understanding in the learning process and what are the next steps for them to encounter. However, with increasing numbers of students in a classroom and increasing teaching workload among teachers, the teachers can gain benefits from these tools in assessing the outcomes quickly and more effectively. Formative assessment contributes to the learning process by providing the teachers with feedback on how successful the teaching method is and how well the students understand a particular lesson. This article will discuss the usage of formative assessment tools in education. It describes and reviews several kinds of literature related to alternative ways to assess students using technology transform assessment in the teaching process. The reviews use a comparison technique using twelve-criteria of technology transform assessment using three formative assessment tools available in the market. It is believed that technology transform assessment can bring an enjoyable and engaging assessment environment in the classroom.
\end{abstract}

Keywords: Formative Assessment, Technology Transform Assessment, Assessment Tools, Enjoyable, Engagement, Kahoot! Quizizz, Socrative, Online Tool, Assessment Application

\section{Introduction}

Formative assessment is a challenge that is faced by educators and pupils in education (Hopkins, Lyle, Hieb, \& Ralston, 2016). Excellency in these subjects depends on 
remembrance of knowledge of content (Messina \& Tabone, 2012). Furthermore, students who demonstrate proficiency in fundamental knowledge of these subject areas often struggle in the application, or transfer their knowledge to new contexts (Hamel, Chaplin-Kramer, Sim, \& Mueller, 2015). Retrieval practice is an easily implemented learning strategy that is important in supporting and enhancing long-term retention and promoting the transfer of learning (Hunter Ball, Klein, \& Brewer, 2014).

Learning process been defined as a change in long-term memory (Kirschner et al., 2006). Many studies have had been conducted regarding effective methods to enhance learning and long-term memory. According to Roediger, \& McDaniel, 2014; Roediger \& Butler, 2011), retrieval practice is a learning strategy that is deeply based in cognitive science principles to enhance long-term retention of information (Butler, Marsh, Slavinsky, \& Baraniuk, 2014). Retrieval practice is the act of recalling facts or concepts from memory and, by doing so, memory for that information is strengthened (Agrawal et al., 2018). Being able to recall information is essential to transfer of learning where existing knowledge is used in new and different contexts (Pan \& Agrawal, 2018). Expertise in a knowledge area is heavily reliant on effective transfer of learning since experts utilize their extensive experiences stored in longterm memory to quickly select and apply the best methodology for solving a problem (Kirschner et al., 2006). Furthermore, "without knowledge you don't have the foundation for the higher-level skills of analysis, synthesis, and creative problem solving" (Brown et al., 2014, p. 18). Thus, strengthening that foundational knowledge using learning strategies such as retrieval practice is a key step in developing those higher-order thinking skills.

Formative assessment is part of reflection of students learning and teaching process (Heck, Cuypers, van de Vrie, Tempelaar, \& van der Kooij, 2013). Therefore, the educators normally apply different methods to achieve the objective of particular lesson (Rao \& Meo, 2016). Technology able to enhance the leaning process and assists assessment activities, during the teaching and learning section and outside of the classroom.

Through formative assessment, teachers able to review students' understanding level, get valuable information on students' learning, and then use that information to modify their teaching methodology. When teachers know what students know (or do not know), they can adjust to meet students right at their level. The best formative assessment tools also help students self-reflect and assess, figuring out where they are and where they need to go as learners. Browse the tools below to find one that meets your needs. There are formative assessment apps for everything from discussion to quizzes, polls, and student responses to interactive lessons and videos.

Effective usage of learning tools, and not an assessment tool, then retrieval practice able to make effective learning (Littrell-Baez, Friend, Caccamise, \& Okochi, 2015). According to (Moreillon, 2015) Several digital tools created for the classroom education bring those exciting experiences to students with learning as the focus. Therefore, mobile applications such Kahoot!, Quizizz, Socrative and mobile range applications use to support learning activities. Normally teachers or lecturers do the assessment to check the understanding level of students in schools (Stone, 2014). Teachers also have responsibility to guide students to involve in studies in active manner. Assessment tools practices have potential to involve being present and students will aware what is happening by using simple tools (Ismail \& Mohammad, 2017). 
According to Maizatul \& Ummu (2018), students who experience formative assessment strategies, particularly low achievers, demonstrate significant learning gains. Through the usage of improved questioning techniques, feedback focusing on how to improve rather than grading, involvement of students in peer assessment and self-assessment, and the use of summative assessments in a formative way, teachers found that the motivation and attitudes of their students improved, and the students achieved higher scores on tests than their peers in the same schools (Deye et. al., 2016). Teaching and learning of educators and pupils challenged by $21^{\text {st }}$ century mobile technology. Therefore, the assessment tools such Kahoot!, Quizizz, and Socrative are being reviewed in this article as the current leading mobile range applications technology that able to support student's inquiry with educational purpose. Formative applications also let students to recognize the differences between productive and non-productive questions. Many educators familiar with these mobile tools and felt easy using them to meet teaching and learning objectives.

\section{Research Background}

Educational instructional is most important in this 21 st century educational field. This is because technology has become the knowledge transformation matter to all human beings (Pusparini, Riandi, \& Sriyati, 2017). Nowadays, a majority of people from all age groups know how to use at least a basic form of technology. Technology tools and equipment have become the main medium of connectivity all over the world and we have the urge and tendency to be connected online (O'Brien, Rogers, \& Fisk, 2012). Development in wireless and mobile technologies introduces a new learning environment called as M-Learning. It offers a different way to deliver learning matters into our daily life (Al-Hunaiyyan, AlSharhan, \& Alhajri, 2017).

Many retrieval practice studies been conducted on learning strategies. More efforts required when learning deeper and longer lasting; retrieval practice feels more challenging and less productive but it results might more tough (Brown et al., 2014). Many affordances to retrieval practice been identified in the literature. First, complex thinking and application skills as well as able to improve the students' organization of knowledge (Agrawal et al., 2018). Human memories can be re-consolidated and strengthen through visual and prior knowledge. Learners able to improve their weaknesses by identifying the strengths and weaknesses when they try to focus on particular thing. (Brown et al., 2014). Lastly, retrieval practice can improve pupils' learning process, where deductive inferences and new contexts made based on knowledge (Eglington \& Kang, 2018). Implementation of some retrieval practices be a key factor in classroom. Spacing required after Several times of learning process. Relaxation after practice over time be much better for long-term information retention (Butler et al., 2014).

Another key factor is the type of practice itself. Continuous practice can be more effective than massed practice (Brown et al., 2014). Different types of problem-solving questions on different topics make the learning process better long term, challenging and effortful. (Agrawal et al., 2018). Furthermore, short answer questions and multiple-choice questions make more effective and improve learning process (Smith \& Karpicke, 2014).

\section{Methodology}

A comparative analysis used qualitatively to analyse the perceived benefits of using Kahoot! over other formative assessment tools. According to (Maher \& Maher, 2018), qualitative research methodology normally focuses on the words and certain attributes of the case being 
discussed. The comparative analysis formative assessment tools were focusing on three dominants formative assessment tools which are the Kahoot!, Quizizz and Socrative.

\section{Formative Assessments}

Formative assessment in school is not just an event, but a combination of strategies that use in classroom that leads towards learning improvement (Ames,1992). Important components involved in formative assessments are such:

a) Discovering, the student learning outcomes;

b) Gathering evidence of the outcomes in lesson;

c) Improving teaching and learning process through the use of the data

As much as assessments can be an accountability tool, it should also be a continuing method for learning. Both formative and summative assessments can be said to contribute to learningcentered teaching. The online and web platforms provide an innovative and positive opportunities for ongoing assessments in the classroom (Center for Teaching Excellence, 2012).

\section{Assessment Tools}

Formative assessment tools such as Kahoot!, Quizizz, and Socrative, are all technological tools that can be described as beneficial to support in the classroom (Bolden, Hurt, \& Richardson, 2017). Kahoot! Quizizz, and Socrative are free games-based quizzing applications. These classroom assessment tools provide assistance to support retrieval practice in the classroom with consideration of planning, quizzes designed with a variety of questions with different strategies for problem solving (Countryman, 2017).

\section{Future of Assessment}

With respect to perceived knowledge retention, formative assessment tools facilitate learning process to retain knowledge and to correct misunderstanding on the subject matters. Technology can help us imagine and redefine assessment in a variety of ways. These tools can provide unobtrusive measurements for learners who are designing and building products, conducting experiments using mobile devices, and manipulating parameters in simulations. Problems can be situated in real-world environments, where students perform tasks, or include multi-stage scenarios that simulate authentic, progressive engagement with the subject matter. Teachers can access information on student's progress and learning throughout the school day, which allows them to adapt instruction to personalize learning or intervene to address particular learning shortfalls. 


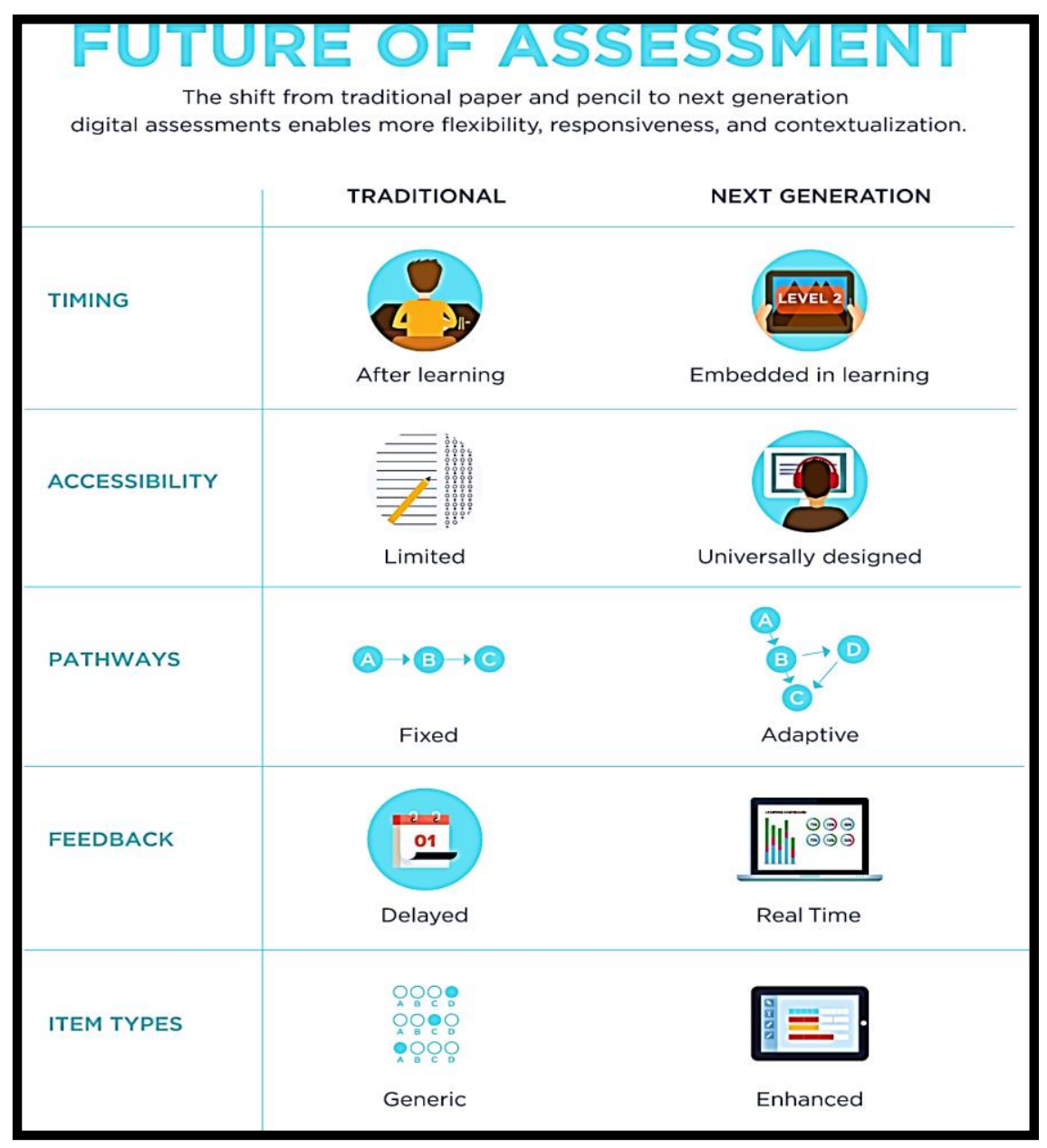

Figure 1: Future of Assessment

Source: https://tech.ed.gov/netp/assessment/

\section{Findings and Results}

\section{Kahoot!}

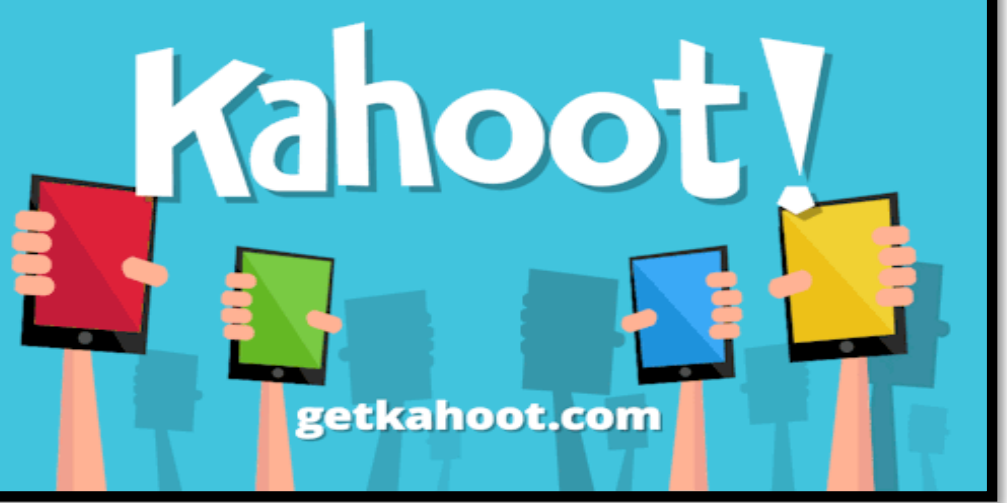

Kahoot! is a free application. Students able to response from almost all platforms. It allows teachers to run games like those multiple-choice answer quizzes (Iwamoto, Hargis, Taitano, \& Vuong, 2017). Teachers can also create their own quizzes or find more quizzes from public 
channel. Questions with choices of answers, projected in front of a classroom screen while students will submit their responses by using an internet-connected device such phones, tablets or computers. According to Bicen \& Kocakoyun (2018) there are questions and polls contain images and video guidance as well. Team mode and Classic mode can take place in within real time, but Challenge mode enables students to take quizzes within period. Thegames-like atmosphere comes from the use of bright multiple colours, suspenseful music, and points given for accuracy of answer and quickness (Plump \& LaRosa, 2017). The Team mode mixes things up and allows groups of students to cooperate with each other and compete against other teams. Kahoot! Does not involve of any accounts, only using pin number displayed from the main screen with given name (Ismail \& Ahmad, 2016).

\section{Quizizz}

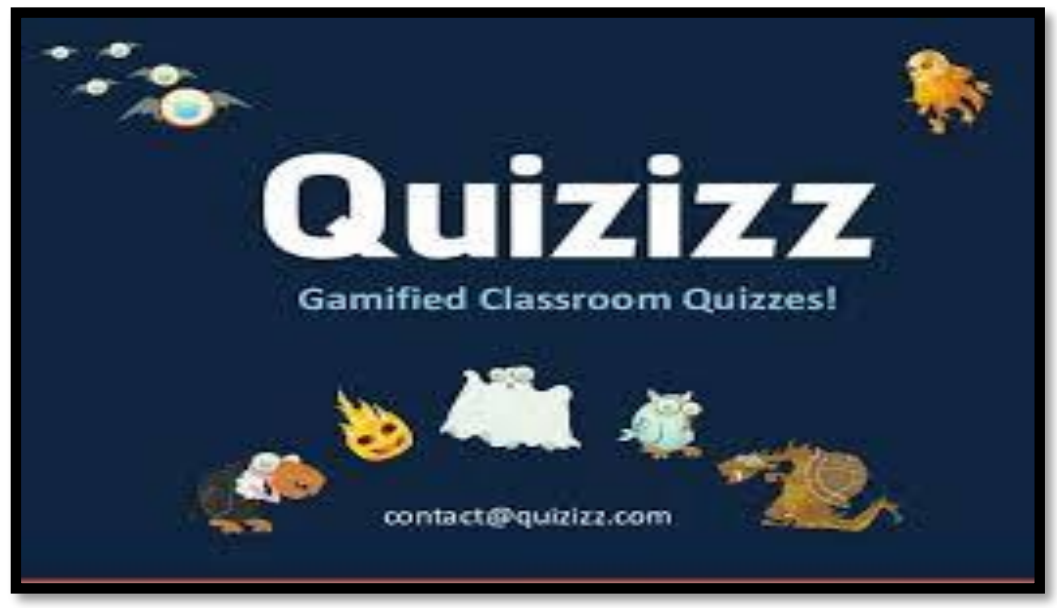

Quizizz is a similar free tool as Kahoot!. It can be used on any devices, web browsers, in different platforms (Bolden et al., 2017). There are thousands of ready-made available Quizizz. Teachers can also create their own. Quizizz can have questions that require reading of a passage or questions that require longer time. Pre-test also available to test-out for learned materials. Students can easily make selection of the choices and choose answers using a browser on a laptop or any mobile devices. According to Mei, Ju, \& Adam (2018), students ranking can be found from leader board during section of the quiz which helpful to have a collaborative environment where competition is not the goal, instead working together this tool can be used to obtain a snapshot of each student's content understanding. Individual student's reports can be printed out for the use of teachers or parents' as references (Zhao, 2019). Students can use nickname or numbers for identification. Students can also sign in by using their Google Account by single click. Students will be notified when they have completed their assignments. Data might update in classroom dashboard. Teachers also have options to make their quiz or for private usage. A created Quizizz can use randomized or nonrandomized questions (Amornchewin, 2018). 


\section{Socrative}

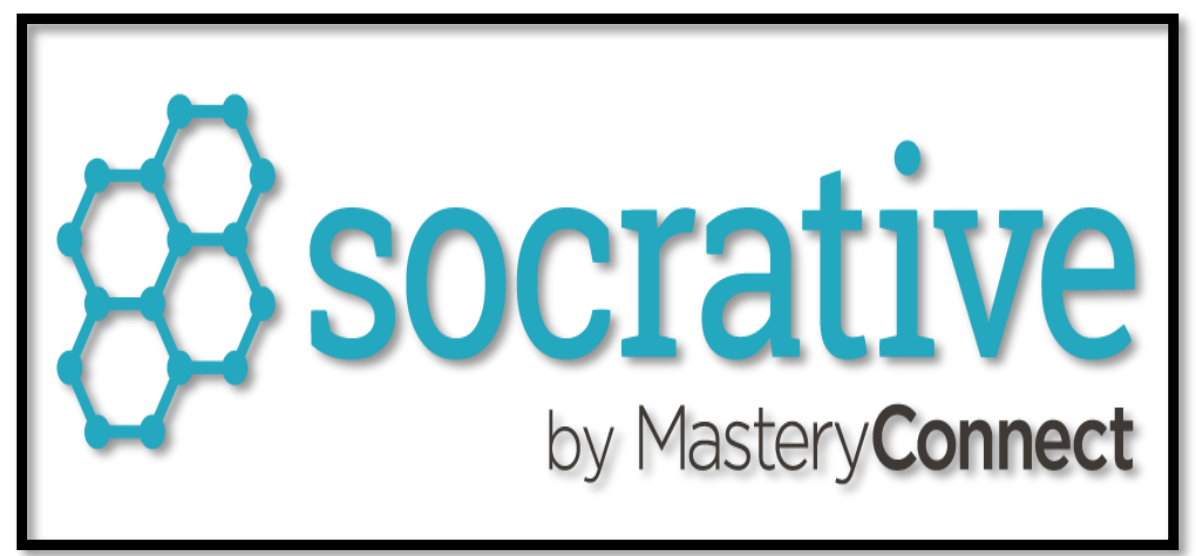

Socrative is an interactive web-based student's response system. Socrative is available through all platforms such iOS and Android that can assist teachers to spark conversation and learning process through created polls and quizzes (Guarascio, Nemecek, \& Zimmerman, 2017). Students able to access the questions via a channel Code, and answers will be recorded immediately on the teacher's computer as the students submit their assignments from all devices. When everyone finishes their responses, teachers can display the results by using "How did we do?" button. Teachers able to create quick questions, quizzes and exit slips that allow for multiple-choice, true/false, and one-sentence-response questions that can produce a grade with feedback for every student (Lim, 2017). Furthermore, basic assessment strategies, students can team up to play Space Race, a collaborative activity where allows student to give quick answers. Teachers also monitor student's progress and download results in an excel format (Balta \& Tzafilkou, 2019).

\section{Comparative Criteria}

Comparative analysis is the process of investigating related but separate scenarios, situations and procedures (The Law Teacher, 2014. The essential rigidity of the dissertation and the worth of its recommendations and conclusion are attained in direct result of the course of comparative analysis. The dissertation becomes, therefore, a series of relatively short, and more manageable, case studies or case histories, rather than a single complex whole involving, necessarily, extremely detailed data and exhaustive analysis of a single event. Comparative analysis is a valid and accepted procedure for acquiring knowledge and understanding, especially in relation to problems that would otherwise be too complex to be manageable (The Law Teacher, 2014).

The findings and results derived from the qualitative analysis of the three case studies of Kahoot!, Quizizz and socrative have been analysed on a point-by point basis. These results will be presented under the following headings: 


\begin{tabular}{|l|c|c|c|}
\hline Criteria and Rationale & Kahoot! & Quizizz & Socrative \\
\hline $\begin{array}{l}\text { Need an account of administrator quiz / } \\
\text { game }\end{array}$ & Yes & No & Yes \\
\hline $\begin{array}{l}\text { Need an account to create and save } \\
\text { Display or popup of question and answer } \\
\text { (Q\&A) on one screen. }\end{array}$ & Yes & Yes & Yes \\
\hline Ability to include images & No & Yes & Yes \\
\hline Options for self-paced or timed & Yes & Yes & Yes \\
\hline Gamified for fun competitive in class & Yes & Yes & Yes \\
\hline Can ask an instant question during a lesson & No & Yes & Yes \\
\hline $\begin{array}{l}\text { Has a ready-made exit ticket that can be } \\
\text { use }\end{array}$ & Not Really & $\begin{array}{r}\text { Not } \\
\text { Really }\end{array}$ & Yes \\
\hline $\begin{array}{l}\text { Ability to search for games made by others } \\
\text { that may act as extra resources if needed }\end{array}$ & Yes & Yes & $\begin{array}{r}\text { Not } \\
\text { Really }\end{array}$ \\
\hline Help and support is available & Yes & Yes & Yes \\
\hline Has a Free Account & Yes & Yes & Yes \\
\hline Can scramble questions and answers & Yes & Yes & Yes \\
\hline
\end{tabular}

Table 1: Comparison of Kahoot!, Quizizz and Socrative criteria

\section{Qualitative}

Interesting Kahoot! contents, including audio-visual components, that helped students repeatedly read content and the associated engagement factors led to repeated interaction with such contents.

Socializing options within video games can enhance motivation.

Table 2: Qualitative Findings Synthesis

\section{Discussions}

Qualitative results strongly indicated that participants engaged by the usage of Kahoot! in the teaching and learning process able to enrich the quality of students' learning in the classroom compare to Quizziz and Socrative. Evidences in the literature support students' finding of digital game related activities gaining entertainment and motivation as a factor that may assist learning (Barab, Thomas, Dodge, Carteaux, \& Tuzun, 2005; Bogost, 2007; Griffiths, 2002; Hainey, Connolly, Stansfield \& Boyle,2011; Paraskeva, Mysirlaki \& Papagianni, 2010; Zarraonandia, Diaz, Aedo \& Ruiz, 2014). Unexpected result was that regardless of the game-show aspect of Kahoot! and gaining of concentration, participants did not identify the game as a competitive experience. This is different than what is talked about in some studies and conceptual literature that highlights. Competition between participants' interest and motivation is the key value of games (Annetta, Minogue, Holmes, \& Cheng, 2009; Burguillo, 2010; Jayakanthan,2002; Ladd, \& Fiske, 2003; Papastergiou, 2009; Vorderer, Hartmann \& 
Klimmt, 2003). Despite the lack of competition, students clearly were engaged, and not only by the gaming experience, but also their perception of the value of the game for learning. Since Kahoot!, Quizizz and Socrative are merely similar in terms of functionality, main features that Kahoot has compare to Quizizz or Socrative are the popularity and the userfriendliness (Maizatul \& Ummu, 2018).

\section{Conclusions}

Evaluating the different online formative assessment tools has given me an insight into the strong and weak points of each of the tools. As a free resource for games-based quizzing applications, Kahoot! makes it an appealing technology transform application for all levels of education. The game-like interface, user-friendliness and upbeat music helps to engage and motivate students during the assessment session. By using the popular games-based quizzing applications available freely, which are Kahoot!, Quizizz and Socrative, teachers can learn how to gamified for a fun competitive assessment activities to be used by current generations of educators for present generation of learners. Overall, a comprehensive assessment tools balances formative and summative student data. With this approach, teachers receive the clearest insight on where a student is relative to his or her peers, their overall education goals, and learning objectives.

\section{References}

Al-Hunaiyyan, A., Al-Sharhan, S., \& Alhajri, R. (2017). A New Mobile Learning Model in the Context of the Smart Classrooms Environment: A Holistic Approach. International Journal of Interactive Mobile Technologies (IJIM). https://doi.org/10.3991/ijim.v11i3.6186

Amornchewin, R. (2018). The Development of SQL Language Skills in Data Definition and Data Manipulation Languages Using Exercises with Quizizz for Students' Learning Engagement. IJIE (Indonesian Journal of Informatics Education). https://doi.org/10.20961/ijie.v2i2.24430

Balta, N., \& Tzafilkou, K. (2019). Using Socrative software for instant formative feedback in physics courses. Education and Information Technologies. https://doi.org/10.1007/s10639-018-9773-8

Bicen, H., \& Kocakoyun, S. (2018). Perceptions of students for gamification approach: Kahoot as a case study. International Journal of Emerging Technologies in Learning. https://doi.org/10.3991/ijet.v13i02.7467

Bolden, D. C., Hurt, J. W., \& Richardson, M. K. (2017). Implementing Digital Tools to Support Student Questioning Abilities: A Collaborative Action Research Report. I.e.: Inquiry in Education.

Countryman, A. M. (2017). Adopting teaching strategies to accommodate different learning styles. NACTA Journal.

Guarascio, A. J., Nemecek, B. D., \& Zimmerman, D. E. (2017). Evaluation of students' perceptions of the Socrative application versus a traditional student response system and its impact on classroom engagement. Currents in Pharmacy Teaching and Learning. https://doi.org/10.1016/j.cptl.2017.05.011

Hamel, P., Chaplin-Kramer, R., Sim, S., \& Mueller, C. (2015). A new approach to modeling the sediment retention service (InVEST 3.0): Case study of the Cape Fear catchment,

North Carolina, USA. Science of the Total Environment. https://doi.org/10.1016/j.scitotenv.2015.04.027

Heck, A., Cuypers, H., van de Vrie, E., Tempelaar, D. T., \& van der Kooij, H. (2013). Formative assessment and learning analytics. https://doi.org/10.1145/2460296.2460337 
Hopkins, R. F., Lyle, K. B., Hieb, J. L., \& Ralston, P. A. S. (2016). Spaced Retrieval Practice Increases College Students' Short- and Long-Term Retention of Mathematics Knowledge. Educational Psychology Review. https://doi.org/10.1007/s10648-0159349

Hunter Ball, B., Klein, K. N., \& Brewer, G. A. (2014). Processing fluency mediates the influence of perceptual information on monitoring learning of educationally relevant materials. Journal of Experimental Psychology: Applied. https://doi.org/10.1037/xap0000023

Ismail, M. A.-A., \& Mohammad, J. A.-M. (2017). Kahoot: A Promising Tool for Formative Assessment in Medical Education. Education in Medicine Journal. https://doi.org/10.21315/eimj2017.9.2.2

Ismail, N. A., \& Ahmad, Z. (2016). Keberkesanan Penggunaan Quizlet dan Kahoot IT dalam Memperkasakan Pengajaran Guru dan Memperkaya Pembelajaran Murid. Seminar Bahasa Melayu.

Iwamoto, D. H., Hargis, J., Taitano, E. J., \& Vuong, K. (2017). Analyzing the efficacy of the testing effect using Kahoot??? on student performance. Turkish Online Journal of Distance Education. https://doi.org/10.17718/tojde.306561

Kahl, S. (2005), Where in the world are formative tests? Right under your nose! Education Week, 25, 38.

Kahoot (2014) How is it Different to Other Classroom Response System. Available at: https://getkahoot.com/ (Accessed: 17 February 2015).

Looney, J. (Ed.). (2005). Formative assessment: improving learning in secondary classrooms. Paris, France: Organisation for Economic Cooperation and Development.

Lim, W. N. (2017). Improving student engagement in higher education through mobile-based interactive teaching model using socrative. In IEEE Global Engineering Education Conference, EDUCON. https://doi.org/10.1109/EDUCON.2017.7942879

Littrell-Baez, M. K., Friend, A., Caccamise, D., \& Okochi, C. (2015). Using retrieval practice and metacognitive skills to improve content learning. Journal of Adolescent and Adult Literacy. https://doi.org/10.1002/jaal.420

Maher, M. J., \& Maher, M. J. (2018). Qualitative methodology. In Racism and Cultural Diversity. https://doi.org/10.4324/9780429479380-42

Maizatul, H.M.Y \& Ummu, H.A. (2018). Pembelajaran Teradun: Trend, Isu dan Amalan. Tanjong Malim: Pejabat Karang Mengarang.

Mei, S. Y., Ju, S. Y., \& Adam, Z. (2018). Implementing Quizizz as Game Based Learning in the Arabic Classroom. European Journal of Social Sciences Education and Research. https://doi.org/10.26417/ejser.v12i1.p208-212

Messina, L., \& Tabone, S. (2012). Integrating Technology into Instructional Practices Focusing on Teacher Knowledge. Procedia - Social and Behavioral Sciences. https://doi.org/10.1016/j.sbspro.2012.05.241

Moreillon, J. (2015). Increasing Interactivity in the Online Learning Environment: Using Digital Tools to Support Students in Socially Constructed Meaning-Making. TechTrends. https://doi.org/10.1007/s11528-015-0851-0

Naeve A. (2013) 'Technology Enhanced Learning', International Journal of Technology Enhanced learning. 33(3), pp. 5-6.

Plump, C. M., \& LaRosa, J. (2017). Using Kahoot! in the Classroom to Create Engagement and Active Learning: A Game-Based Technology Solution for eLearning Novices. Management Teaching Review. https://doi.org/10.1177/2379298116689783

Pusparini, F., Riandi, R., \& Sriyati, S. (2017). Developing Technological Pedagogical Content Knowledge (TPACK) in Animal Physiology. In Journal of Physics: Conference Series. https://doi.org/10.1088/1742-6596/895/1/012059 
Rao, K., \& Meo, G. (2016). Using Universal Design for Learning to Design Standards-Based Lessons. SAGE Open. https://doi.org/10.1177/2158244016680688

Siemens, G. (2005) 'Connectivism: A learning theory for the digital age', International Journal for Instructional Technology and Distance Learning, 2(1), pp 3-10.

Siemens, G. and Conole, G. (2011) Special issue-Connectivism: Design and delivery of social networked learning. International Review of Research in Open and Distance Learning, 12, p3.

Stone, E. M. (2014). Guiding students to develop an understanding of scientific inquiry: A science skills approach to instruction and assessment. CBE Life Sciences Education.

We Are Human (2015) Kahoot, a design-led, web-based educational platform. Available at: http://www.wearehuman.cc/ (Accessed: 19 February 2015).

Wilson, M. (2015) Case Study Research Design. Available at: https://explorable.com/casestudy-research-design (Accessed: 22 February 2015).

Wisker G., (2008). The postgraduate Research handbook. 2nd Ed. Hampshire: Palgrave Macmillan.

Zhao, F. (2019). Using Quizizz to Integrate Fun Multiplayer Activity in the Accounting Classroom. International Journal of Higher Education. https://doi.org/10.5430/ijhe.v8n1p37 